\title{
日本の体力医学の源流と変遷
}

\author{
栗原 敏 ${ }^{1}$, 鈴木 政登 ${ }^{1}$, 清田 寛 ${ }^{2}$
}

\section{History of Physical Fitness and Sports Medicine in Japan}

\author{
Satoshi Kurihara ${ }^{1}$, Masato Suzuki ${ }^{1}$ and Hiroshi Kiyota ${ }^{2}$ \\ ${ }^{1}$ 東京慈恵会医科大学, ₹ 105-8461 東京都港区西新橋3-25-8 (The Jikei University School of Medicine, 3-25-8 Nishi-Shin- \\ bashi, Minato-ku, Tokyo 105-8461, Japan) \\ ${ }^{2}$ 日本体育大学，＝158-8508 東京都世田谷区深沢7-1-1 (Nippon Sport Science University, 7-1-1 Fukazawa, Setagaya-ku, To- \\ kyo 158-8508, Japan)
}

Received / Accepted: February 7, 2014

\begin{abstract}
Kanehiro Takaki, the founder of The Jikei University School of Medicine suggested that a nutritional factor was important for preventing beri-beri, which was a common disease in the Meiji era in Japan and Southeast Asia. He improved the rations fed to crews of the Imperial Japanese Navy to include wheat and meat. The rations he devised effectively prevented beri-beri. Some 30 years later, vitamin $B_{1}$ was discovered, and a deficiency of vitamin $B_{1}$ was found to be the cause of beri-beri. Takaki believed that nutrition and exercise were important for keeping our bodies fit. He often gave lectures on how people could keep fit to prevent diseases. Thus, his activities are considered to be the beginning of preventive medicine in Japan. The contributions of Takaki to the physical fitness of the Japanese people have been continued by the graduates of The Jikei University School of Medicine. Some of the graduates became professors of The Jikei University School of Medicine and Tokyo University of Education (now, Tsukuba University). Thus, both universities have the common basis and tradition for research and education in the fields of physical fitness and sports medicine, and have collaborated with each other in these fields. In this article, we provide a brief overview of the history of the development of research regarding physical fitness and sports medicine in Japan. We discuss the contribution of various persons including our graduates, to the health and physical fitness of the Japanese people.
\end{abstract}

Jpn J Phys Fitness Sports Med, 63(2): 247-257 (2014)

Keywords : physical fitness, sports medicine, beri-beri, vitamin $\mathrm{B}_{1}$

\section{はじめに}

東京慈恵会医科大学の創設者高木兼寛は, 大学の前身 成医会講習所を明治14年（1881年）に開設し，その 4 年 後（明治18年）（1885年）, 日本で最初の看護婦教育所を 創設した，明治15年（1882年）には施療病院を開院する とともに，脚気発症の原因は栄養の欠陥であることを指 摘した，さらに，国民の健康，体力，衛生などに関する 啓蒙活動を行い，健康維持・増進や衛生に関する著書を 刊行し, 日本の体力医学の源流を創った一人であると考 えられる，そこで，この講演では，高木兼寛から始まる 日本の体力医学研究の変遷と, 日本体力医学会の創設訃 ら今日に到るまでの歴史を考察した。日本体力医学会の 創設に関する記録は, 日本体力医学会の機関誌 ·体力科 学などに報告されているが, これまでとは異なる視点で 俯瞰した。

\section{明治時代の日本人と西洋人の体格と体型11}

明治時代の日本人は西洋人に比較して, 低身長, 短足, $\mathrm{O}$ 脚, 猫背，などの特徵があり，体格が貧弱で姿勢が悪 かった，富国強兵の時代に，西洋人に比べて国民の体格 が劣っていることは国として大きな問題であった，明治 20 年代の日本人の平均寿命は男 42.7 歳, 女 44.3 歳で, 日 本人の体格を示すと, 例えば,

男 身長 $157 \mathrm{~cm}$, 体重 $50 \mathrm{~kg}$

女 身長 $145 \mathrm{~cm}$, 体重 $45 \mathrm{~kg}$

であったという報告がある。

明治時代は感染症と脚気が死因の上位を占めており, 特に青年期に多発していた結核と脚気の予防は国として の重要課題であった，脚気は“あしの気”、“江戸わずら い”などといわれ, 知覚障害, 運動障害が扔こり, 最後は, 脚気衝心といわれる心不全で苦悶のうちに死亡するとい う病で恐れられていた。軍隊では兵士が脚気になると歩 
行困難になり，脚気は戦力に多大な影響をおよぼしてい た，東京慈恵会医科大学の創設者で，後に海軍軍医総監 になった高木兼寛は脚気を何とか予防したいと考えた。

\section{高木兼寛と脚気の撲滅}

高木兼寛は宮崎県高岡町穆佐村に生まれ，脚気の撲滅 を目指して医師を志した。当初, 明治政府は英国医学を 導入したいと考えていたが, 優れた細菌学の研究成果を あげていたドイツ医学に注目し，方針を変えドイッ医学 を導入することを決めた，それに伴い明治政府が英国か ら招聘した医師， ウイリアム・ウィリス（William Willis）は解雇され, 鹿児島藩医として雇用されることになっ た，医学を学ぶために，穆佐村から鹿児島に遊学した高 木兼寛はウィリスと出会い, その後の人生が決まったの である。

高木はウィリスの優れた医術を見て感動し，西欧に留 学して医学を学びたいと考えた。 ウィリスの勧めで海軍 に入り, 次いで英国のセントトーマス病院医学校 (St. Thomas' Medical School) (現在は King's College と合併) に 5 年間留学し, 優秀な成績を収めて明治13年（1880年） に帰国した（Fig. 1).

ドイッでは，ローベルト・コッホ（Robert Koch）が 病原菌を次々に発見していたので, 多くの疾病は細菌に よって誘起されると考える医学者が多かった，脚気も細 菌による感染でおこると考えられていた，高木は脚気 患者の発症場所, 患者周囲の環境などをつぶさに調べ, 脚気の発症には食事の栄養素が関係しているという考
えに至った（Fig. 2)，高木は英国留学中に使った, “A Manual of Practical Hygiene” (実際衛生学)を紐解きヒ ントを得たのである，そこには，西欧の健康な青年の食 事に含まれる窒素と炭素の比は 1 対15であると記載さ れていた，しかし，日本の青年の食事の窒素・炭素比は 1 対20-28であった。 そこで, 高木は窒素・炭素比を変 えた食事の献立をいろいろ作り, 窒素・炭素比が高い食 事を摂ると脚気になることを明らかにした。

高木は日本で最初の大規模介入試験を計画した。海軍 の練習艦 “龍驤”と“筑波”を使って遠洋航海をさせ，そ れぞれの練習艦の乗員の食事の献立を変えて脚気の発症 を比較するというものであった。明治15年 (1882年), 練 習艦 “龍驤”の乗員は従来の兵食を摂り,太平洋を 272 日 間で一周する遠洋航海を終えて帰国したところ, 脚気に よる25名の死者が出ていた，これは，海軍軍医の高木に とって一大事であった，高木は練習艦 “筑波”を使って， 兵士に高木が考案したパン, 牛乳, 肉を多くした窒素・ 炭素比が低い食事を摂らせ, “龍驤”と同様に太平洋を 一周させて脚気の発症を比較する航海実験を計画した。 しかし，資金がなかった，時の総理大臣・伊藤博文に相 談したところ, 伊藤の計らいで明治天皇に拝謁して, 脚 気栄養欠陥説を説明することになった。明治天皇も脚気 に悩んでいた。明治天皇は高木の計画に賛意を示し，高 木は航海実験のための資金を調達することができた，明 治17年 (1884年), 高木の提唱する食事を摂って287日間 の航海をして帰国した練習艦“筑波”の兵士の中から 14 名の軽症脚気患者が出たが，死者は出なかった，脚気に

\section{高木兼寛（1849-1920）}

宮崎県東諸県郡高岡町穆佐村

出身、下級武士の息子

鹿児島藩の開成学校に学び

William Willis（英国人医師）

と出会い西欧の医学に感動

海軍に入る

英国St.Thomas' Hospital Medical Schoolに医学生と して留学 (1875-1880)

䴚国後、海軍軍医総監

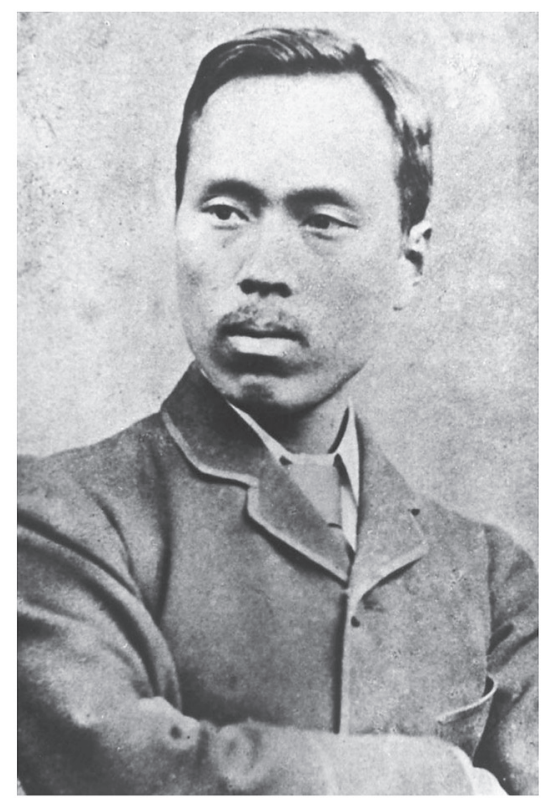

Fig. 1 A short personal history of Kanehiro Takaki.

He was born in Mukasa village of Miyazaki Prefecture as a son of a lower-class samurai. He went to Kagoshima Prefecture and met Dr. William Willis, a Scottish physician. Takaki was influenced by Willis and intended to study British medicine. 


\section{脚気は伝染病か ---高木兼寛はこう考えた---}

1. 日本と東南アジアに多発していた (欧米にはない) 生活様式、特に食事と関係があると考え調査研究を行った (疫学的手法)（英国で学んだことが影響している） (ドイツ学派は分析的研究)

2. 生活環境 (温度、湿度、衣、住など) とは関係ない

3. 感染症の可能性が指摘されていた (ドイツ学派) 感染経路、不潔な場所での発生頻度などを調べたが 感染とは考えにくかった

4. 食事と関係があると考え調べた

"Edmund Alexander Parkes, A Mannual of Practical Hygiene”を参考にして西欧男子の栄養摂取を調べた 西欧の男子の栄養摂取は窒素と炭素の比が1:15であった

Fig. 2 Takaki's consideration about the cause of beri-beri.

Takaki thought that beri-beri was not an infectious disease but was related to nutrition.

かかった者は，ミルクを飲まなかったなど，高木が考え た食事を摂らなかったことが分かった。この航海実験の 結果を知り, 高木は脚気栄養欠陥説を一層確信するよう になったのである。

高木は肉食, パン食, 麦飯が脚気の予防に有効である ことを示し，海軍では食事を改善したので脚気に罹患す る兵士が激減した。また, 脚気による死者が無くなった。 そして，脚気を予防するには，白米でなく麦飯を食べる ことが有効であることを提唱した。 しかし，脚気細菌説 を唱える陸軍を中心とした人々との間で論争となり，日 本では脚気栄養欠陥説は受け入れられなかった。この経 緯は, 森林太郎(鴎外)との脚気論争 ${ }^{2}$ として知られている. 脚気に麦飯が有効だという高木の主張には学理がないと 言って, 脚気栄養欠陥説を受け入れなかった陸軍では, 脚気患者と脚気死亡者が相変わらず続出していた ${ }^{2-4)}$.

高木の仕事から約30年後に，オランダの衛生学者クリ スチャン・エイクマン (Christian Eijkman) は脚気の予 防に米糠の中の成分が有効であることを報告し, 抗脚気 因子があるというグリインス（Gerrit Grijns）と同様の 考えに到達した.グリインスは論文を英文で発表してい なかったので, 広く知られなかった。エイクマンはノー ベル生理学医学賞を受賞し, 高木が兵食を改善して海軍 から脚気を駆逐したことをノーベル賞受賞講演で紹介し 讃えた. 高木の研究には学理はなかったかもしれないが, ビタミンという概念がなかった当時，致し方なかった． しかし, 食事を改善して脚気患者と脚気による死亡者を 激減させた功績は大きい.

\section{高木兼寛の啓蒙活動}

高木は国民の衛生と疾病の予防が重要と考え，国民を 対象に啓蒙活動を精力的に行った（大正元年からの 8 年間に1,388回の講演を行ったと言われている (Fig. 3). この活動は現在の予防医学の先駆けと言ってよい. 高木 は，衣食住から礼儀作法などに至るまで5)，健康に資す ると思われることを著書, “心身修養6)”, “心身強健法7)” （Fig. 4）に記述している。また，高木邸に国民体育奨励 会8)の事務所を置いて, 啓蒙活動を精力的に行った。講 演会では，高木が考案した“舟漕ぎ体操”を実演し普及 に努めた. 体を摇することが健康に良いと考えたようで, これが改良されて, 後のラジオ体操へと発展した。国民 体操研究所所長で慈恵医学校体操教員だった松元稲穂が 改良したとされている。

\section{高木兼寛と加納治五郎 ${ }^{9)}$}

高木兼寛と共に国民の体格，体力，体育に関心をもっ ていたのが加納治五郎であった（Fig. 5). 加納治五郎は 明治26年（1893年） 6 月，高等師範学校長を命ぜられた。 以前から，体育の重要性を主張していたので，高等師範 学校に体操専修科を創設した。また, 優れた柔道指導者 を育成するために，柔道教員養成所を開設した（明治44 年 (1912年) 4 月). 開設の目的は, 将来, 柔道教師とし て活躍できる人材を育成しようというもので，柔道の専 門学科に加えて, 倫理学を遠藤隆吉, 生理学を片山國幸 （後に慈恵医大整形外科の初代教授に就任）に担当させ て教授した (Fig. 6)。 また，内閣総理大臣・寺内正毅の 


\section{高木兼寛は国民の健康と疾病の予防に尽力した}

○身修養6)

高木兼寛著、東京廣文堂 大正5年(1916年)発行

心身強健法7)

高木兼寛著、東京株式会社 東亞堂蔵版

、體育奨励に関する実行條項説明書

大正 8 年(1919年) 発行

大正6年(1917年) 発行

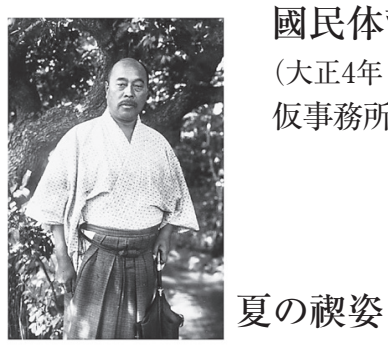

民体育奨励会8

大正4年(1915年)東京高等師範学校教授＼cjkstart佐々木吉三郎らと共に設立)

夏の楔姿

食事、運動、住居、衣服、衛生に言及

Fig. 3 The contribution of Takaki to the health and prevention of diseases in the Japanese people.

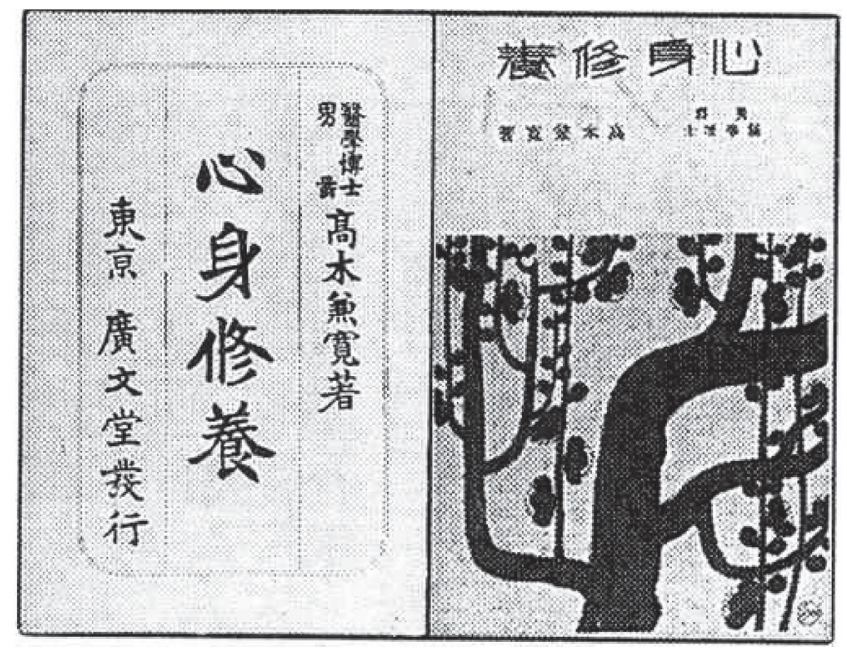

Fig. 4 One of Takaki's publications regarding the training to keep bodies fit.

下に設置された臨時教育会議 (大正 6 年から 2 年間開催) （1917年）の委員に，加納治五郎と高木兼寛が名前を連 ねていて，二人は，体力ゃ体育の重要性とともに道徳教 育の充実を強調していた。

加納治五郎は，昭和 7 年（1932年） 2 月 1 日，神田一 ツ橋の学士会館で講道館柔道医学研究会を発足させた。 片山國幸 (慈恵医大整形外科学·教授) と浦本政三郎（慈 恵医大生理学・教授）が, この研究会のメンバーになっ ており，後に東京都知事を務めた東龍太郎の名前も見ら れる，このような史実から，高木兼寛と加納治五郎との 関倸は相当強かったものと考えられる。この関倸から後
に,東京慈恵会医科大学と東京教育大学(現在の筑波大学) に関係する多くの教授が輩出され，その門下から多数の 体力医学研究者や教育者が育成されたのである (Fig. 7).

晚年，高木兼寛自身は，川面凡児という禊の指導者か ら裙の手ほどきを受け，心身の鍛錬に裙を取り入れて熱 中した。また，慈恵医大·生理学教授だった生沼曹六は, 身体機能に対する禊の影響に関する生理学的研究を行っ たという記録がある。生沼教授の後任，浦本政三郎教授 は, 国民の体力に高い関心を寄せ，体力医学研究を行う とともに日本体力医学会の設立に尽力した。この様に, 疾病を治療するだけでなく, 健康の維持・増進, 体力の 向上，道德を重んじた高木兼寬の啓蒙活動は次世代へと 継承されていったのである。

\section{日本体力医学会の設立前後の体力医学研究の流れ ${ }^{10)}$}

大正10年（1921年）に労働科学研究所が設立され, 睴 峻義等が所長に就任し, 労働衛生学の研究を行った（暉 峻義等は, William Harveyの “動物の心臓ならびに血液 の運動に関する解剖学的研究”を翻訳出版（岩波書店） したことでも知られている). 大正11年（1922年）には日 本生理学会が創立され, 生体の生理機能の研究が推進さ れた。また，国立体育研究所が開設され，北豊吉が所長 に就任した（Fig. 8).

昭和 2 年 (1927年) にはスポーツ医事研究会が発足し, 日本体育協会医事部，体育医学相談所，日本体育協会又 ポーツ科学研究所 (昭和38年 (1963年)) へと変遷してい く，その間，昭和 3 年（1928年）に文部省体育運動審議 


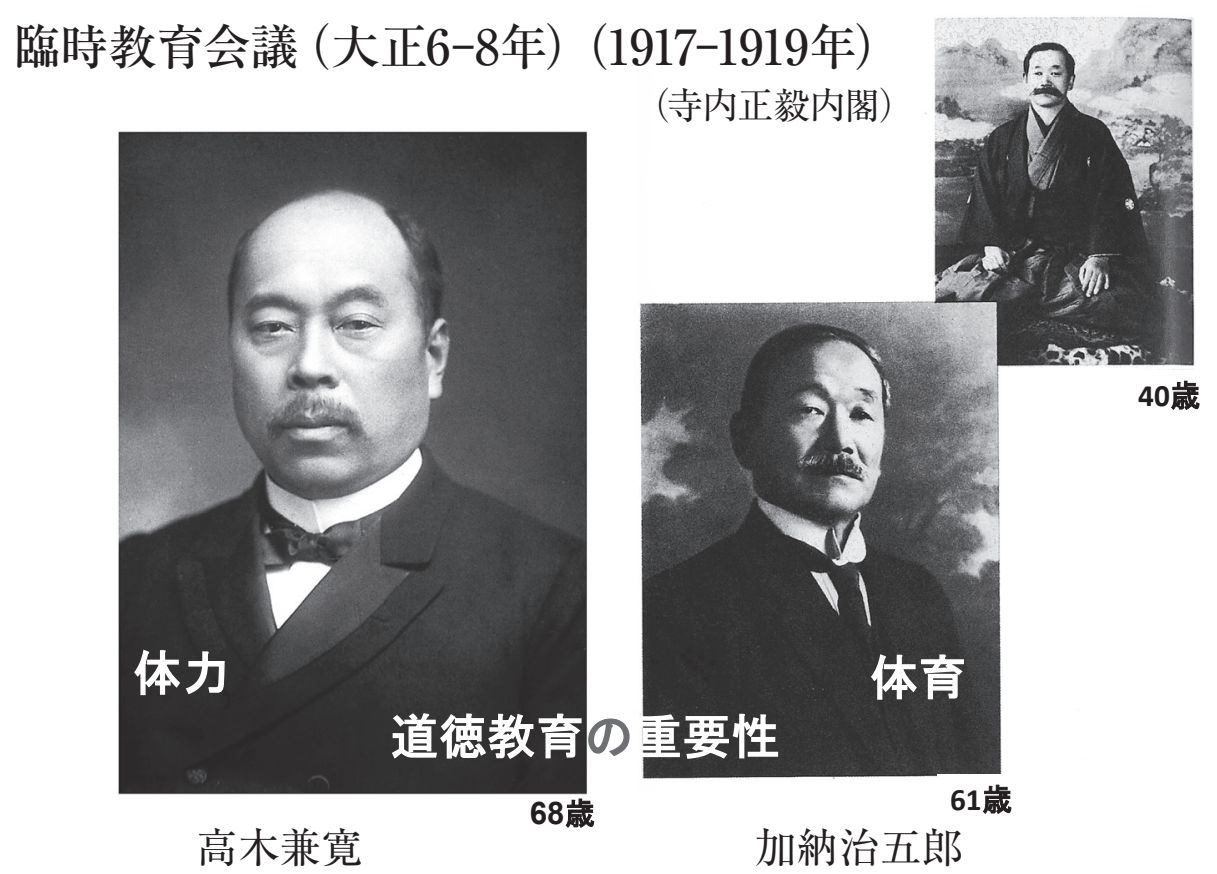

Fig. 5 Takaki and Jigorou Kanou were members of an interim committee for education in the government of Prime Minister Terauchi.

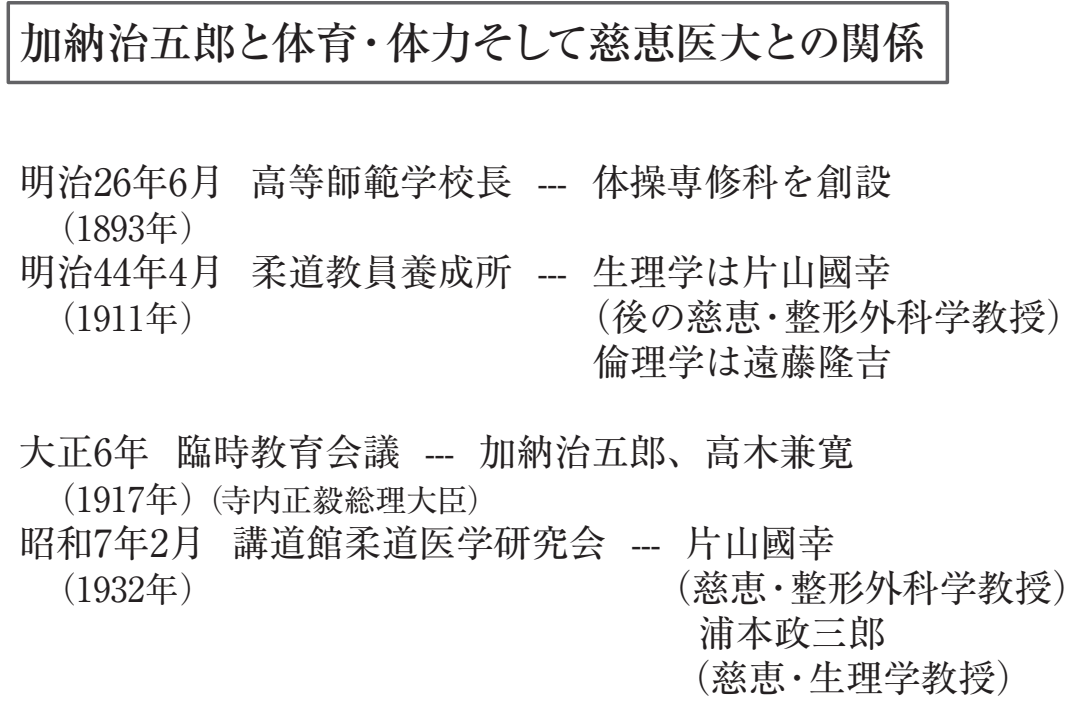

Fig. 6 Kanou's works related to physical fitness and the involvement of the staffs of The Jikei University School of Medicine in his activities.

会が発足し，昭和16年（1941年）には公衆衛生院の前身 である厚生科学研究所が設立され, その中に, 体力衛生 課，体力測定課，国民体力課の 3 課が設置された.

昭和16年（1941年），旧学術研究会議医学部門の共同 研究班に体力研究班, 疲労研究班, 労働衛生班が設けら れたが，昭和23年（1948年）に日本学術会議が発足して この共同研究班は解消した。

共同研究班の解消に伴い, 昭和24年(1949年) 3 月28日, 第一回学会設立準備委員会が開催された。委員には以下
の方々の名前が見られる. 東龍太郎, 東俊郎, 阿部勝馬, 大森憲太, 勝木新次, 小池敬事, 小島三郎, 佐々貫之, 古屋芳雄, 斎藤潔, 斎藤一男, 塚田治作, 福田邦三, 白 井伊三郎, 原島進, 三木行治, 吉川春壽. そして, 世話 人として, 浦本政三郎, 名取禮二, 石川知福, 東龍太郎 が協力した（Fig. 8)。学会の設立に際して，学会の名称 を “日本体力医学会”とし, 学会誌の名称を “体力科学” とすることなどが話し合われ，決められた．

そして，昭和24年（1949年）に日本体力医学会が設立 


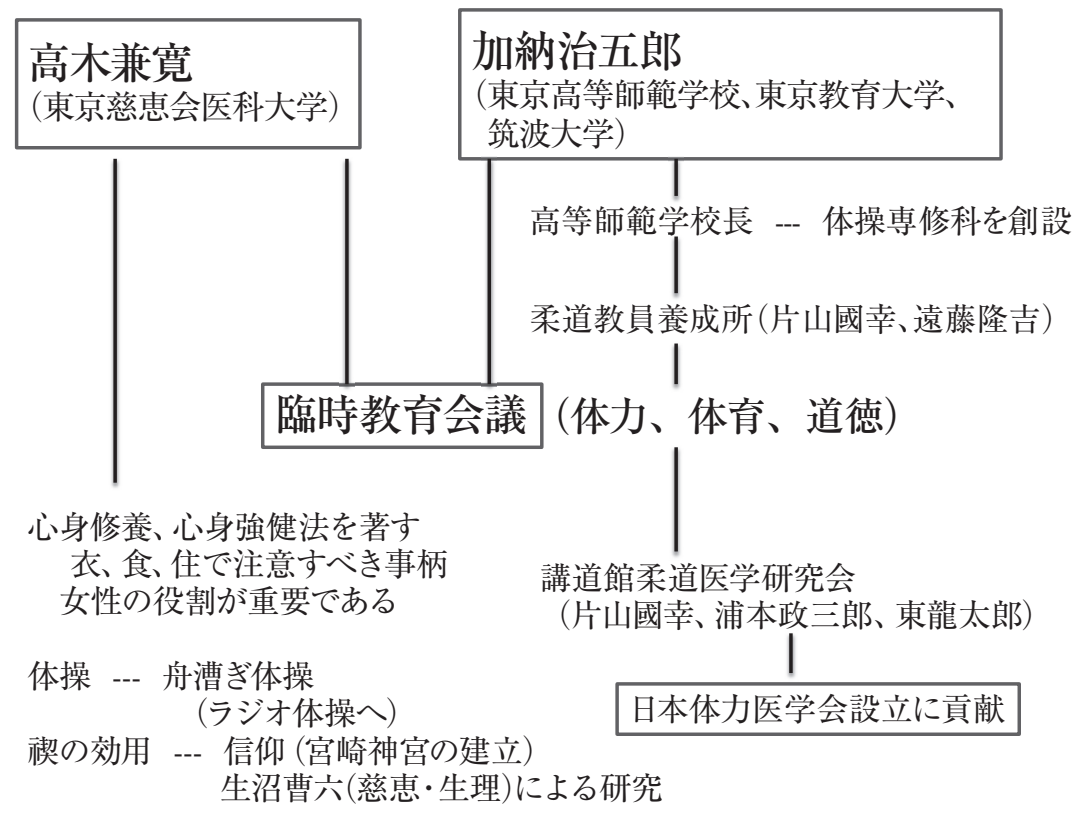

Fig. 7 Flow chart of the activities of Takaki and Kanou regarding education (knowledge, physical fitness and morals) before the establishment of the Japanese Society of Physical Fitness and Sports Medicine.

\section{日本体力医学会設立前後}

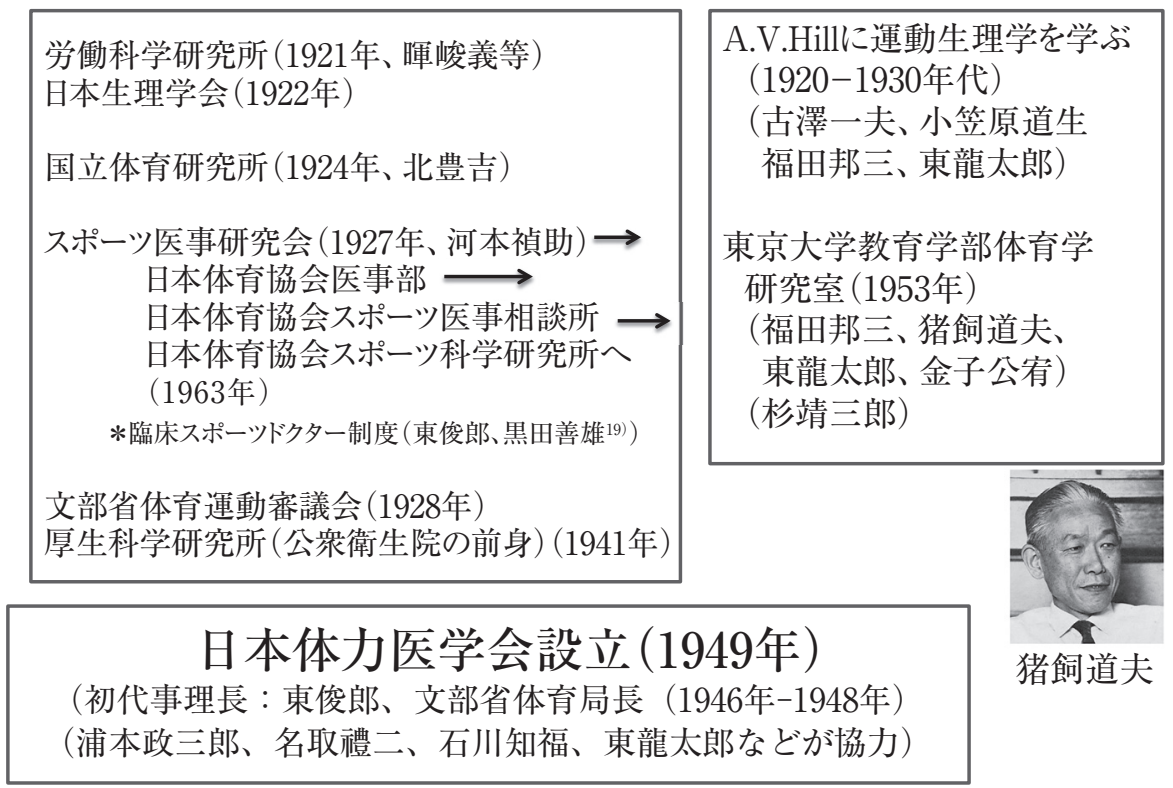

Fig. 8 The activities regarding the physical fitness and sports medicine in the year before and after the establishment of the Japanese Society of Physical Fitness and Sports Medicine.

された ${ }^{11,12)}$ のである。初代理事長には，昭和21年から 23 年（1946年から1948年）まで文部省体育局長を務めてい た東俊郎が就任し, 浦本政三郎は初代の評議員会長に選 出された。

このような中で, 運動生理学的研究に注目する研究者 も出てきて, 東京大学教育学部体育学研究室 (現, 東京 大学大学院教育学研究科) が開設され（昭和 28 年, 1953
年), 福田邦三, 東龍太郎, 猪飼道夫 ${ }^{13)}$, 金子公宥らが研 究を推進した。英国ロンドン大学ユニバーシティカレッ ジのヒル教授（A.V.Hill）の下で研究した人々が州国し て活躍したのである ${ }^{14,15)}$ 。筋の熱発生でノーベル生理学 医学賞を受賞したHillは，基礎研究の成果を人体に適用 することを試みた。 Hillの下には, 古澤一夫, 福田邦三, 小笠原道生，東龍太郎などが留学して，多大な影響を受 
>昭和16年(1941年) 厚生科学研究所 (公衆衛生院の前身)

国民体力部が設けられて以下の3課が設置された

体力衛生課、体力測定課、国民体力課

昭和16年(1941年) 旧学術研究会議医学部門

共同研究班 (体力研究班、疲労研究班、労働衛生班)

○昭和23年(1948年)に日本学術会議が発足し共同研究班は解消

昭和24年(1949年)3月28日、第一回学会設立準備委員会

東龍太郎、東俊郎、阿部勝馬、大森憲太、勝木新次、小池敬事、小島三郎、佐々貫之、 古屋芳雄、斎藤潔、斎藤一男、塚田治作、福田邦三、白井伊三郎、原島進、三木行治、 吉川春壽 (世話人: 浦本政三郎、石川知福、名取禮二)

•日本体力医学会が発足 (1949年、昭和24年)

浦本政三郎が日本体力医学会発足の経緯を“体力医学”

(学術会議体力研究班編集、1948年)に記述

Fig. 9 The establishment of the Japanese Society of Physical Fitness and Sports Medicine.

けて帰国した.ここに日本の運動生理学, あるいはスポー ツ科学の大きな流れが創られ現在に至っている（古澤一 夫は日本で最初に最大酸素摂取量を測定したと言われて いる)。また, 東京大学医学部生理学教室で, 橋田邦彦 教授の下で生理学を学んだ杉靖三郎が，昭和30年（1955 年) 8 月から東京教育大学体育学部に移動し, 筋生理学 や運動生理学の研究を行うと共に, 国民の健康や疾病の 予防などに関する啓蒙活動を盛んに行い，多くの門下生 を育成したのである。

\section{体力医学研究の変遷}

戦前は国力という観点で国民の体力が重要視されてい たが，戦後は，個人の健康あるいはスポーツという視点 から体力医学研究が推進されたという指摘がある. 戦前. 戦後に打ける体力医学研究の対象と考え方の変化につい て, 森川貞夫 (日本体育大学名誉教授 $)^{16)}$ は, 浦本政三郎 (慈恵医大・生理学教授) の以下のような記述を紹介し ている。“戦前は国家の国力としての体力という視点で 体力が研究されていた。 しかし, 戦後は文化的に個々人 の自覚に基づく関心が強くなり，かつてスポーッマンで あったり，あるいはスポーツ愛好者であった医学者によ り純学問的な関心から, 体力医学分野が開拓された”"17). 森川は, 浦本がこの記述の中で戦前に扔ける国家として の体力には触れていないことに注目し, 戦前・戦後の体 力医学研究の視点と方向が異なってきたと述べている.

\section{東京慈恵会医科大学と東京教育大学（筑波大学）に おける体力医学研究}

東京慈恵会医科大学では高木兼寛の影響と考えられる が, 浦本政三郎 (慈恵医大・生理学教授, 初代の日本体
力医学会評議員会長), 名取禮二 (慈恵医大 - 第一生理 学教授, 第 7 代学長, 第 2 代日本体力医学会理事長), 杉 本良一 (慈恵医大・第二生理学教授), 阿部三亥 (慈恵医 大出身で杉本教授の指導を受けた），大塚正八郎（慈恵 医大出身), 小川新吉 (元慈恵医大 - 生理学講師, 東京教 育大学教授), 酒井敏夫 (慈恵医大 - 第二生理学教授), 佐伯侲 (慈恵医大·宇宙医学研究室教授), 中野昭一（日 本体育大学 - 東海大学名誉教授, 元慈恵医大生理学 - 助 教授), 小野三翮 (東京学芸大学教授, 元慈恵医大客員教授) らが, 体力医学研究を推進した. その影響を受けて多数 の研究者が育成され, 今日の体力医学研究を担っている (Fig. 10).

杉本良一は，昭和23年から昭和30年（1948年から 1955 年）まで，東京教育大学の教授を兼務した。阿部三亥は 福島師範学校, 東京高等師範学校を卒業した後, 慈恵医 大に入学し, 昭和18年（1943年）に卒業した後, 杉本教 授の指導を受け, その後, 東京教育大学の教授に就任し た。両大学でサッカーの指導にあたった。昭和19年に慈 恵医大を卒業した小川新吉は昭和26年（1951年）に東京 教育大学助手に就任し, その後, 同大学付属スポーツ研 究所教授に就任した。また，大塚正八郎は慈恵医大を昭 和19年に卒業した後, 昭和27年（1952年）に東京教育大 学に移り, 健康管理学の教授に就任, 改組によって筑波 大学に変わってからも教授を務めた，慈恵医大第一解剖 学教授であった森田茂は昭和15年（1940年）に慈恵医大 を卒業し, 昭和29年（1954年）に東京教育大学体育学部 助教授に就任, 人体形態学研究室の初代教授となり, そ の後, 慈恵医大の第一解剖学講座の教授として, 人類学 的研究を中心に推進し活躍した.

この様に, 高木兼寛と加納治五郎との出会いが, その 
後の東京慈恵会医科大学と東京教育大学（現, 筑波大学） との大学間の教育と研究の交流に発展した。高木と加納 は後世まで日本の体力医学研究者の育成に多大な影響を およぼしたと言える。また，A.V.Hillに続く東京大学教 育学部大学院は, 運動生理学を中心に実に多くの人材を 輩出し, 日本の体力医学, スポーツ科学を牽引してきた.

東京慈恵会医科大学は医学部のみを有する大学である が，これまで，スポーツの分野で活躍する人材を多数輩 出してきたのは高木兼寛の影響と考えられる。例えば, 高木兼寛の長男, 高木喜寛は日本ラグビーフットボール 協会の初代理事長を務めた。高木兼寞の外孫の樋口一成 は, 自身が水泳選手として日本記録を持ち, 極東オリン ピック（上海）（1925年）に選手として参加したばかりで なく, 第 3 代日本水泳連盟会長を務めた (Fig. 11). スポー ツ医学科の大畠襄は, 国際サッカー連盟の医学委員, 日 本サッカー協会のスポーツ医学委員を務め, 医師として 初めてサッカー殿堂入りしている (平成22年 (2010年)).

\section{日本体力医学会の活動}

日本体力医学会は，1949年の設立以来会員数は増え,
現在，4,979名が学会員として活躍している（2013年 8 月 31日現在). 毎年, 国民体育大会が開催される都道府県で 日本体力医学会大会が開催され, 今年で第68回を迎えた。 第 4 回国民体育大会が広島で開催された時に, 日本体力 医学会大会が開催され，以後, 毎年, 国民体育大会と日 本体力医学会大会が同時に開催されるようになった．

大会の開催とともに, 機関誌 “体力科学” と “Journal of Physical Fitness and Sports Medicine (JPFSM)" の 刊行, スポーツ医学研修会の開催, それに連動した日本 体力医学会健康科学アドバイザー制度の実施, プロジェ クト研究の推進, 日本体力医学会賞の授与, 国際スポー ツ医学会,アジアスポーツ医学会との連携など，日本体 力医学会の活動範囲は拡大しつつある.

また，研究分野も多様になってきた，設立当初は，体 力測定, 疲労, 労衝衛生が, 研究の大きな柱であったが, 最近では, 生化学, 分子生物学, 遺伝子, 免疫学などの 研究発表が増えて㧍り, これらの分野は今後, 若い世代 の研究者によって一層発展することが期待されている. また，研究者は医学を修めたいわゆる医学部出身者より も，それ以外の分野を専攻した人たちの割合が増えてき

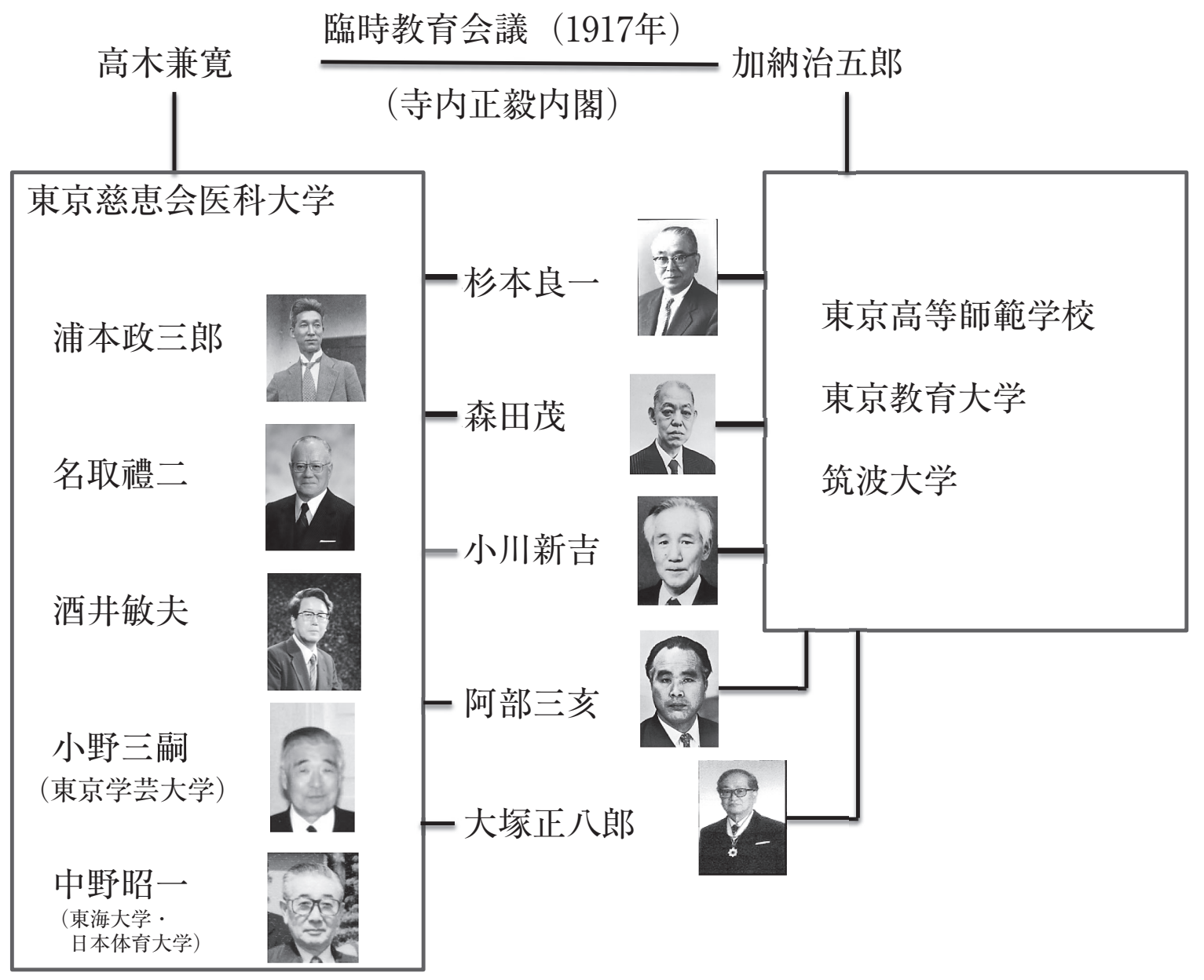

Fig. 10 The graduates of The Jikei University School of Medicine who worked in the field of physical fitness and sports medicine. Some of them became professors of The Tokyo University of Education. 


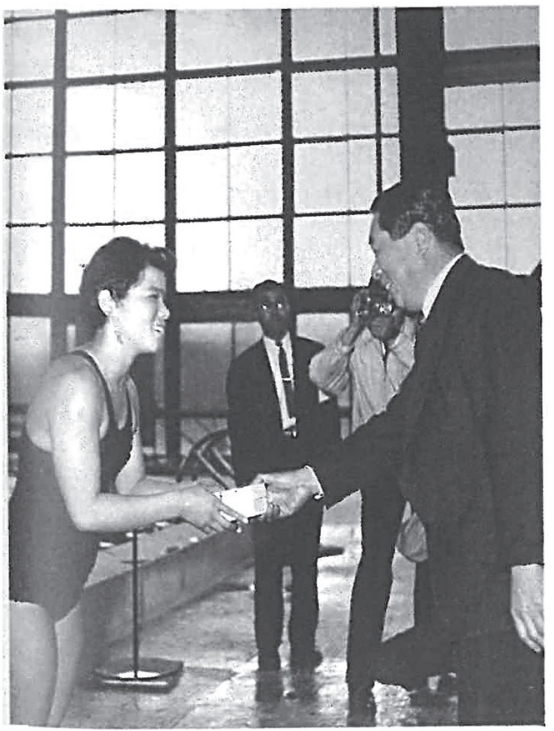

水泳連盟会長時代 ローマオリンピック銅メダリスト田中瞈子選手と

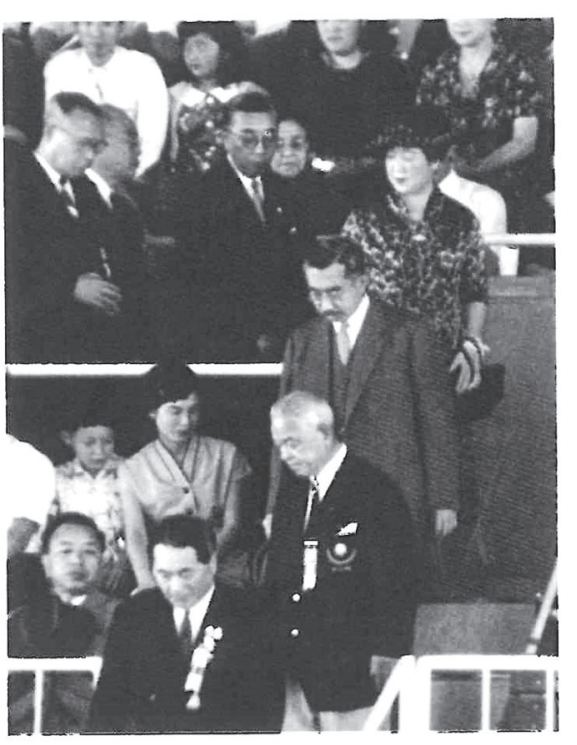

天皇·皇后両陛下と

\section{第3代日本水泳連盟会長（樋口一成 第6代学長）}

Fig. 11 Professor Kazushige Higuchi, the 6th President of The Jikei University School of Medicine (a grandson of Kanehiro Takaki). He was the 3rd president of the Swimming Association of Japan. He guided the Emperor and Empress (right photograph) and he presented a medal to Satoko Tanaka, a Japanese swimmer and Olympic bronze medalist (left photograph).

た。しかし，日本医学会の第39分科会であることを考慮 して, 理事会のメンバーは, 医学部出身者と他分野出身 者の割合を $50 \%$ ずつに定め, 学会運営の円滑化を図っ ている.

\section{設立当時における体力医学研究の考え方について}

日本体力医学会が発足した当時, すでに，東俊郎初代 理事長や，浦本政三郎教授は，実践者と基礎科学者の協 力が必須であり, 理論体力科学と実践体力科学連携の重 要性を論じている ${ }^{11,12)}$ (Fig. 12). 現在の研究様式と照ら し合わせて考えてみると, 分析的研究とともに統合（総 合）的研究が体力科学には必要で, 相互に補完し合うこ とが求められている17)ということになるだろう.

第 2 代理事長を務めた名取禮二は機関誌・体力科学 に以下のような特別寄稿 ${ }^{18)}$ をている。“体力医学研究 は，常に人を考え，人体の部分的な研究にとどまらず, 心身全体を対象として考えるところに特徴があり, 時に は厳密でないところがあるが, 研究を積み上げることに よって正確性が高まっていく，従って，体力医学研究が 時として，低く見られることがあるが，それだけ体力医 学が複雑な対象を扱っているからと考えられる”。名取 禮二は，骨格筋の単一筋線維を取り出して細胞膜を油の 中で剥離し，筋原線維を取り出すことに成功した。この 筋線維剥離標本は, 名取のスキンドファイバーと命名さ れ，多くの筋生理学者が研究に用いた。このスキンド
ファイバーには筋原線維とともに，筋小胞体や横行小管 (transverse tubules, T管) が存在しており, 名取はスキ ンドファイバーを電気刺激すると収縮することを報告し た.内部膜の存在を示唆したが, その後, 筋小胞体や T 管が電子顕微鏡で発見され，実証された。このように， 細胞という生命の一単位をさらに分析することによっ て，新たな知見が得られたが，これを筋細胞（筋線維） の収縮・弛緩との関係で考えるには，様々な研究が必要 で, 分析的研究とともに統合的（総合的）研究が必要で ある。また，生体内の骨格筋の働きを考えると，さらに 一層, 複雑なメカニズムを考えることが求められるよう になる。

分析的研究と統合 (総合) 的研究の橋渡しが常に必要と なるが, 分析的研究結果の集合が必ずしも, 全体に当ては まるとは限らない，そこに体力医学研究の難しさがある.

また, 最近では, 研究倫理の問題が議論されており, 特に人を対象とした研究には倫理審査を受けることが必 須である。しかし, 研究者が所属する大学で倫理審査が できないところがあり，問題となっている，さらに，利 益相反についての申告も学会発表や論文発表で求められ ており，学会としての見解を明確にすることが必要とな りつつある。

\section{今後の学会活動に対する期待を込めて}

高齢社会を迎えた日本は，誰しもが健やかに生きたい 


\section{体力科学の意味するところ （体力科学、第1号、1950年2月10日）}

発刊の言葉 (日本体力医学会理事長 東俊郎)

体力科学は、体力、疲労、労働衛生など広範囲を対象

実証的科学的研究を行う

体力科学の研究成果は体育の実践に対する基礎となる

体力医学序説 (浦本政三郎)

体力は具体的実証的である

科学と題したことは、医学の立場を一歩進めている

力は量的に把握されることが科学的なのである (定量性)

健康は体内の動植物機能の動的平衡による (全機性)

体力は基礎科学を総動員してはじめてはっきりする

実践体力科学と理論体力科学

1950年に日本体育学会が設立され、現在の “体育学研究” が発刊された

Fig. 12 Philosophical consideration of physical fitness and sports medicine.

The purpose and meaning of physical fitness and sports medicine.

と願っている。しかし，歳を重ねるにしたがって体力は 低下し, 社会的活動は制限され, それに伴って精神活動 も衰えてくる。高齢社会における生き方に対してはいろ いろな提言があるが，一人一人が自分自身を見すえ，相 応に努力することが求められる.

名取禮二は, 晚年, 挨拶の時に, “康寧を願って”と一 言添えていた。 心身ともに健やかでありたいという先生 の気持ちが込められていたと感じる。名取は, “体力医 学にはスポーツ障害の防止やその治療など臨床医学の仕 事も含まれるが, 元来が健康の科学であり, 大きな課題 は人々が生涯を通じて, 心身ともに健やかに, 活動力に 満ち, 働くことに生きがいを覚える上で役立つであろう 学的基礎知識を与えることにある”と述べている.

この第68回日本体力医学会大会は, 国民の康寧に寄与 できる大会でありたいと考えた。 それには，栄養をいか に摂るか, 日頃から適切な身体運動を心掛け, そして休 養をどのように取り入れるのかということに尽きる。 日 本体力医学会にはそのための有用な情報を国民に提供す ることが求められていることを確認したい。 もちろん, 人間の限界に挑戦するトップアスリートを対象とした研 究も重要な分野で, そのための研究成果が一般人に還元 されることは多々あり, このような研究の振興も必要で ある、

この小論を書いている最中, 2020年にオリンピック · パラリンピックが東京で開催されることが決まった。 1964年以来の東京でのオリンピック開催となる。1964年 のオリンピックでは, 日本体力医学会の主要メンバーが, 各競技を手分けして支援したという経緯がある。臨床ス ポーツドクター制度 ${ }^{19)}$ が出来ている現在, 2020年のオリ
ンピック・パラリンピックに向けて，日本体力医学会が 積極的に協力できれば幸いである。

\section{謝 辞}

この小論をまとめるにあたり，貴重な資料を提供して下 さった，金沢大学人間社会研究域学校教育系の大久保英哲 教授, 並びに, 龍谷大学文学部の佐々木浩雄准教授に深甚 の謝意を表します。

\section{文献}

1）エルヴィン・ベルツ（及川茂訳）. 日本人の身体的特徵, ベルツ日本文化論集, 東海大学出版会, 東京, 369-376, 2001.

2) 山下政三. 鴎外森林太郎と脚気紛争, 日本評論社, 東京, 2008.

3）松田 誠. 東京慈恵会医科大学の源流-高木兼寛の医学笹気出版印刷, 東京, 2007.

4）板倉聖宣. 模倣の時代 (上, 下), 仮説社, 東京, 1988.

5）松田 誠: 高木兼寛の女子教育論, 慈恵医大誌, 124: 2134, 2009.

6）高木兼寛. 心身修養, 東京廣文堂, 東京, 1916 .

7）高木兼寛. 心身強健法, 東亞堂蔵版, 東京, 1919.

8）國民体育奨励会（高木兼寛），體育奨励に関する実行條 項説明書, 三秀社, 東京, 1917.

9）加納治五郎先生伝記編纂会 (布井達雄). 加納治五郎, 講 道館, 布井書房, 東京, 1964.

10）小野三翮. 日本における体力医学研究の歴史と展望, 大 修館, 東京, pp17-102, 1991.

11）東 俊郎：発刊のことば, 体力科学, 1: 1, 1951.

12) 浦本政三郎：体力科学序説, 体力科学, 1:2-5, 1951.

13）猪飼道夫：日本における最近の体力科学とスポーツ科 学の発展, 体育の科学, 15: 663-669, 1965.

14）宮下充正. スポーツ科学ー草創期から 21 世紀一, スポー 
ツの科学, 財団法人日本学術協力財団, 東京, 14-25, 2007.

15）金子公宥. スポーツ科学の基礎を築いた研究者-A.V.Hill と猪飼道夫ースポーツの科学, 財団法人日本学術協力 財団, 東京, 26-37, 2007.

16）森川貞夫.「体力」を歴史的に問うことの意味, 成田十次 郎先生退官記念論文集 体育・スポーツ史研究の展望一 国際的成果と課題一, 不昧堂出版, 東京, 535-551, 1996.
17) 浦本政三郎：体力医学の学問的環境, 体力科学, 1 (2): 1, 1951.

18）名取禮二：体力医学の生い立ち, 体力科学, 39: 93-98, 1990.

19）黑田善雄教授定年退官記念会 (代表 - 浅見俊雄). 道標 ースポーツ医科学の歩んだ道・進む道, 1985. 